\title{
Determinants of protein evolutionary rates in light of ENCODE functional genomics
}

\author{
Nadezda Kryuchkova ${ }^{1,2^{*}}$, Marc Robinson-Rechavi ${ }^{1,2}$ \\ From Ninth International Society for Computational Biology (ISCB) Student Council Symposium 2013 \\ Berlin, Germany. 19 July 2013
}

\section{Background}

The influence of different parameters, from gene size to expression levels, on the evolution of proteins has been previously studied mostly in yeast [1] and Drosophila [2]. The main feature which has been found to explain protein evolutionary rate was the level of gene expression, especially in yeast.

\section{Results}

Here we investigate these relations further, and extend them to mammals, especially taking in account gene expression in different organs. For expression we used the RNA-seq data from ENCODE [3] for 22 different tissues of mouse. We used ENCODE data to define which transcript is used as reference to compute features such as gene length or intron number. The relation between evolutionary rate and six gene features: gene expression, gene expression specificity, intron number, intron length, protein length and GC\% content were analyzed. We use partial correlation to take into account dependencies between them. We find strong differences between tissues in the impact of expression on evolutionary rate (Figure 1 and http://f1000.com/posters/browse/summary/1094165). Over all tissues, an interesting result is that evolutionary rate shows no strong correlation with expression level in mouse if corrected for other parameters.

\section{Conclusions}

Dependencies between gene features need to be taken into account for an unbiased view of gene evolution. Overall results are consistent with those in Drosophila [2]. We find important differences between tissues in the relation between expression and evolutionary rate, especially for the central nervous system and testis.

'Department of Ecology and Evolution, University of Lausanne, 1015

Lausanne, Switzerland

Full list of author information is available at the end of the article
Authors' details

'Department of Ecology and Evolution, University of Lausanne, 1015

Lausanne, Switzerland. 'Swiss Institute of Bioinformatics (SIB), 1015 Lausanne, Switzerland.

Published: 11 February 2014

References

1. Pál C, Papp B, Lercher MJ: An integrated view of protein evolution. Nat Rev Genet 2006, 7(5):337-48.

2. Larracuente AM, Sackton TB, Greenberg AJ, Wong A, Singh ND, Sturgill D, Zhang Y, Oliver B, Clark AG: Evolution of protein-coding genes in Drosophila. Trends Genet 2008, 24(3):114-23.

3. ENCODE Project Consortium: A user's guide to the encyclopedia of DNA elements (ENCODE). PLOS Biol 2011, 9(4):e1001046.

doi:10.1186/1471-2105-15-S3-A9

Cite this article as: Kryuchkova and Robinson-Rechavi: Determinants of protein evolutionary rates in light of ENCODE functional genomics. BMC Bioinformatics 2014 15(Suppl 3):A9.
Submit your next manuscript to BioMed Central and take full advantage of:

- Convenient online submission

- Thorough peer review

- No space constraints or color figure charges

- Immediate publication on acceptance

- Inclusion in PubMed, CAS, Scopus and Google Scholar

- Research which is freely available for redistribution
() Biomed Central
C Biomed Central

(c) 2014 Kryuchkova and Robinson-Rechavi; licensee BioMed Central Ltd. This is an Open Access article distributed under the terms of the Creative Commons Attribution License (http://creativecommons.org/licenses/by/2.0), which permits unrestricted use, distribution, and reproduction in any medium, provided the original work is properly cited. The Creative Commons Public Domain Dedication waiver (http://creativecommons.org/publicdomain/zero/1.0/) applies to the data made available in this article, unless otherwise stated. 


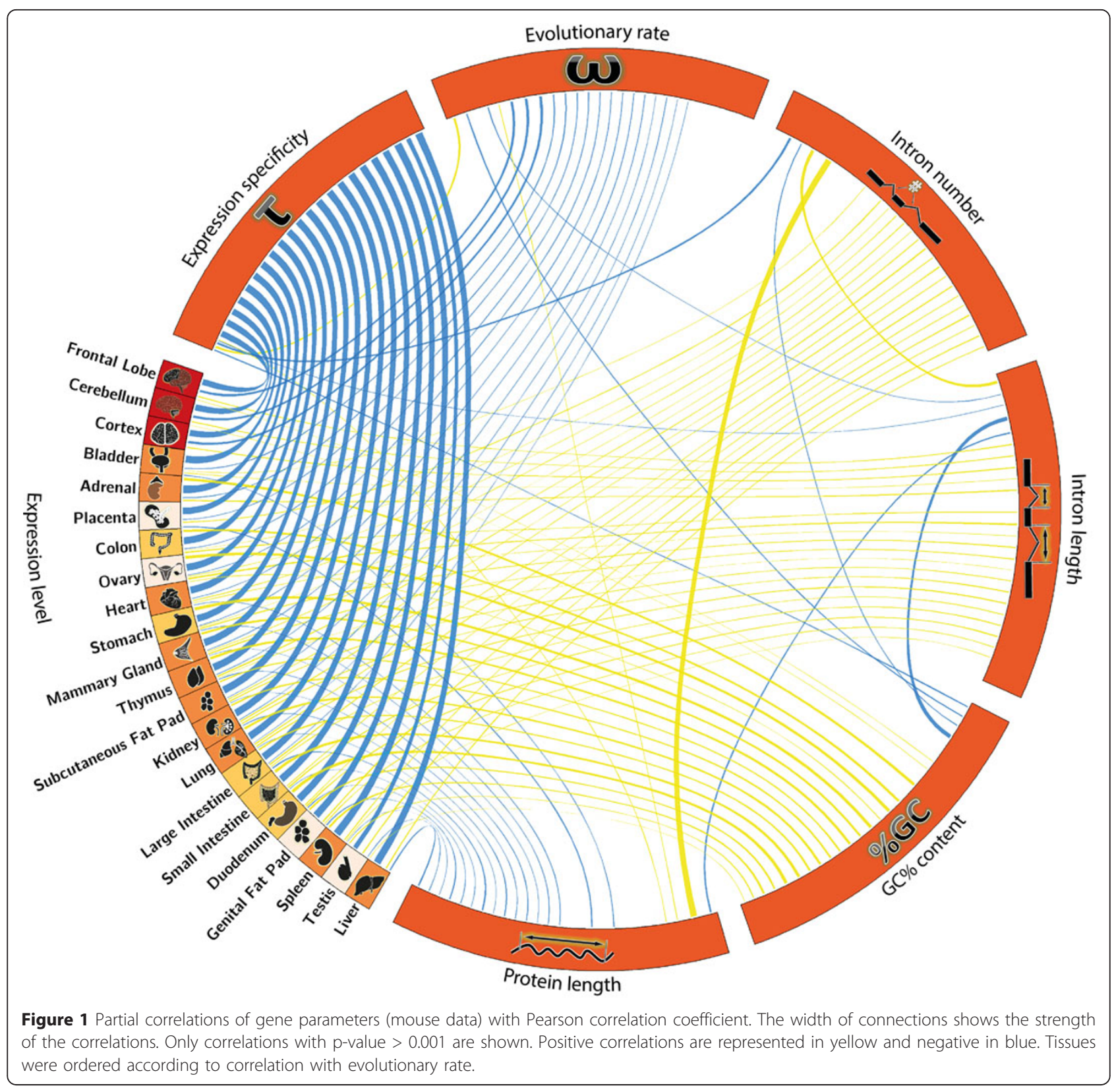

